\title{
Leaf number and plant height of three Canna $x$ generalis cultivars
}

\author{
Zsiláné-André, A. ${ }^{1}$, Somogyi, A. ${ }^{1}$ \& Holb, I.J. ${ }^{1,2}$ \\ ${ }^{1}$ University of Debrecen, Institute of Horticulture P.O. Box 36, H-4015 Debrecen, Hungary \\ ${ }^{2}$ Plant Protection Institute, Centre for Agricultural Research, Hungarian Academy of Sciences, P.O. Box 102, H-1525 Budapest, \\ Hungary, author for correspondence: Holb, I.J. (holbimre@gmail.com)
}

\begin{abstract}
Summary: The aim of this three-year study was to evaluate the effect of three treatments (thiophanate methyl, charcoal dust, and control) on leaf number and plant height on three Canna x generalis cultivars (City of Portland, Richard Wallace and Robert Kemp). Results showed that the 3-year means of leaf number ranged from 13.9 to 23.1 for the three cultivars. The largest leaf numbers were for cultivar Robert Camp (23.1 in 2010) and the lowest for cultivar City of Portland (13.9 in 2011). Thiophanate methyl treatment produced the highest number of leaves and the values were significantly different at $\mathrm{P}<0.05$ from the control for all years and for all cultivars. Numbers of leaves in charcoal dust treatments were larger than the control treatments but it was not significantly different. Results on plant height ranged from 69.2 to $160.5 \mathrm{~cm}$ for the three cultivars. The largest plant height was for cultivar Robert Kemp (160.5 cm in 2011) and the lowest for cultivar City of Portland (69.2 cm in 2011). Thiophanate methyl treatment produced the highest plant height and the values were significantly different at $\mathrm{P}<0.05$ from the control for all years and for all cultivars. Plant heights in charcoal dust treatments were larger than the control treatments but it was not significantly different.
\end{abstract}

Zsiláné-André, A., Somogyi, A., Holb, I.J. (2017): Leaf number and plant height of three Canna x generalis cultivars. International Journal of Horticultural Science 23(1-4): 22-24. https://doi.org/10.31421/IJHS/23/1-4./1197

Key words: Canna $x$ generalis, leaf numbers, plant height, thiophanate methyl, charcoal dust

\section{Introduction}

Canna $\times$ generalis L.H. Bailey, is an important ornamental plant decorating gardens (Maas-van de Kamer and Maas, 2008). This plant bears large beautiful flowers and attractive leaves (Doi et al., 2013). It is usually propagated vegetatively mainly through its rhizomes (Wróblewska et al., 2014). Several cultivars of $C$. $x$ generalis are known form the beginning of last century. Flower and leaf features are usually described in most studies and marketing enterprises (Zhang et al., 2004, Yeh et al., 2004). These plants are used mainly for city parks as decorating streets. As this ornamental is a large plant can provides additional fresh air for the citizens. Large plant height and large number of leaves for a cultivar can be useful for human health and for a city marketing (Broschat et al., 2008).

The aim of this study was to evaluate the effect of three seasonal fungicide treatments (thiophanate methyl, charcoal dust, and control) on leaf number and plant height on three Canna $x$ generalis cultivars (City of Portland, Richard Wallace and Robert Kemp).

\section{Materials and methods}

\section{Location, plant material and orchard management}

A 3-year study (2009, 2010 and 2011) was carried out in an experimental research station in Eastern Hungary, located in Debrecen-Pallag $\left(47^{\circ} 31^{\prime} 60^{\prime \prime} \mathrm{N}, 21^{\circ} 37^{\prime} 60^{\prime \prime} \mathrm{E}\right)$, consisted of a cultivar collection of $C$. $x$ generalis, including cultivars City of Portland, Richard Wallace and Robert Kemp. Research station soil type was brown forest soil with alternating layers of clay. The pest management program followed the Hungarian integrated fruit production (IFP) guidelines (Cross and Dickler, 1994). Three chemical treatments (thiophanate methyl, charcoal dust, and control) were used during the season. Stable manure and compost were applied in March of every other year. The plants were irrigated twice per year during dry periods in July and August.

\section{Plant height and leaf number assessments}

From the cultivar collection of $C$. $x$ generalis, including cultivars of City of Portland, Richard Wallace and Robert Kemp were selected for plant height and leaf number assessments in 2009, 2010, and 2011. Four plots were performed for each cultivar. Each plot consisted of 20 plants for each cultivar. When plants reach the seasonal heights at the end of the summer, plant height was measured then numbers of leaves were counted for each cultivar in all the three years.

\section{Data analyses}

Measurements of plant height and number of leaves were used to characterize cultivars in all years. Both measurements were averaged to obtain a single value for each year and cultivar. Then, data of each measurement were analysed by analysis of variance. Then means for each measurement were separated by a least significant difference (LSD) test using $\mathrm{LSD}_{0.05}$ values. Prior to the analyses, all incidence values were arcsine-square root transformed in order to make the data normally distributed. 
Table 1. Leaf number of three Canna x generalis cultivars under three treatments (thiophanate methyl, charcoal dust control) at Debrecen-Pallag, Hungary $(2009,2010$ and 2011).

\begin{tabular}{|c|c|c|c|c|}
\hline Cultivar/treatments & 2009 & 2010 & 2011 & Overall \\
\hline \multicolumn{5}{|l|}{ City of Portland } \\
\hline Thiophanate methyl & $17.3 \mathrm{~b}$ & $18.1 \mathrm{~b}$ & $19.9 \mathrm{~b}$ & $18.4 \mathrm{~b}$ \\
\hline Charcoal dust & $15.1 \mathrm{a}$ & $16.5 \mathrm{ab}$ & $15.2 \mathrm{a}$ & $15.6 \mathrm{a}$ \\
\hline Contol & $14.0 \mathrm{a}$ & $14.7 \mathrm{a}$ & $13.9 \mathrm{a}$ & $14.2 \mathrm{a}$ \\
\hline \multicolumn{5}{|l|}{ Richard Wallace } \\
\hline Thiophanate methyl & $18.1 \mathrm{~b}$ & $18.7 \mathrm{~b}$ & $19.2 \mathrm{~b}$ & $18.7 \mathrm{~b}$ \\
\hline Charcoal dust & $15.8 \mathrm{a}$ & $16.4 \mathrm{a}$ & $16.7 \mathrm{a}$ & $16.3 \mathrm{a}$ \\
\hline Contol & $14.8 \mathrm{a}$ & $15.5 \mathrm{a}$ & $15.8 \mathrm{a}$ & $15.4 \mathrm{a}$ \\
\hline \multicolumn{5}{|l|}{ Robert Kemp } \\
\hline Thiophanate methyl & $21.2 \mathrm{~b}$ & $23.1 \mathrm{~b}$ & $22.9 \mathrm{~b}$ & $22.4 \mathrm{~b}$ \\
\hline Charcoal dust & $16.9 \mathrm{a}$ & $18.8 \mathrm{a}$ & $18.5 \mathrm{a}$ & $18.1 \mathrm{a}$ \\
\hline Contol & $16.1 \mathrm{a}$ & $17.2 \mathrm{a}$ & $17.3 \mathrm{a}$ & $16.9 \mathrm{a}$ \\
\hline
\end{tabular}

Table 2. Plant height $(\mathrm{cm})$ of three Canna x generalis cultivars under three treatments (thiophanate methyl, charcoal dust control) at Debrecen-Pallag, Hungary $(2009,2010$ and 2011).

\begin{tabular}{|c|c|c|c|c|}
\hline Cultivar/treatments & 2009 & 2010 & 2011 & Overall \\
\hline \multicolumn{5}{|l|}{ City of Portland } \\
\hline Thiophanate methyl & $94.4 \mathrm{c}$ & $95.3 \mathrm{c}$ & $90.5 \mathrm{~b}$ & $93.4 \mathrm{~b}$ \\
\hline Charcoal dust & $78.3 \mathrm{a}$ & $75.7 \mathrm{a}$ & $73.2 \mathrm{a}$ & $75.7 \mathrm{a}$ \\
\hline Control & $69.8 \mathrm{a}$ & $70.8 \mathrm{a}$ & $69.2 \mathrm{a}$ & $69.9 \mathrm{a}$ \\
\hline \multicolumn{5}{|l|}{ Richard Wallace } \\
\hline Thiophanate methyl & $121.1 \mathrm{~b}$ & $120.1 \mathrm{~b}$ & $120.8 \mathrm{~b}$ & $120.7 \mathrm{~b}$ \\
\hline Charcoal dust & $111.6 \mathrm{a}$ & $116.4 \mathrm{~b}$ & $108.9 \mathrm{a}$ & $112.3 \mathrm{a}$ \\
\hline Control & $108.2 \mathrm{a}$ & $107.7 \mathrm{a}$ & $106.6 \mathrm{a}$ & $107.5 \mathrm{a}$ \\
\hline \multicolumn{5}{|l|}{ Robert Kemp } \\
\hline Thiophanate methyl & $156.3 \mathrm{~b}$ & $157.1 \mathrm{~b}$ & $160.5 \mathrm{~b}$ & $157.9 \mathrm{~b}$ \\
\hline Charcoal dust & $137.2 \mathrm{a}$ & $133.9 \mathrm{a}$ & $138.3 \mathrm{a}$ & $136.5 \mathrm{a}$ \\
\hline Control & $124.6 \mathrm{a}$ & $130.1 \mathrm{a}$ & $127.5 \mathrm{a}$ & $127.4 \mathrm{a}$ \\
\hline
\end{tabular}

\section{Results}

\section{Leaf number}

Analyses of variance on leaf number indicated significant $(P<0.05)$ differences amongst years and cultivars. There were no significant interactions amongst treatment factors.

The 3-year means of leaf number ranged from 13.9 to 23.1 for the three cultivars and from 13.9 to 19.9 for cultivar City of Portland, and from 14.8 to 19.2 for cultivar Richard Wallace and from 16.1 to 23.1 for cultivar Robert Kemp (Table 1). The largest leaf numbers were for cultivar Robert Camp (23.1 in 2010) and the lowest for cultivar City of Portland (13.9 in 2011). Thiophanate methyl treatment produced the highest number of leaves and the values were significantly different at $P<0.05$ from the control for all years and for all cultivars. Numbers of leaves in charcoal dust treatments were larger than the control treatments but it was not significantly different.

\section{Plant height}

Analyses of variance on plant height indicated significant $(P<0.05)$ differences amongst years and cultivars. There were no significant interactions amongst treatment factors.

The 3-year means of plant height ranged from 69.2 to 160.5 $\mathrm{cm}$ for the three cultivars and from 69.2 to $95.3 \mathrm{~cm}$ for cultivar City of Portland, and from 106.6 to $121.1 \mathrm{~cm}$ for cultivar Richard Wallace and from 124.6 to $160.5 \mathrm{~cm}$ for cultivar Robert Kemp (Table 2). The largest plant height was for cultivar Robert Camp (160.5 cm in 2011) and the lowest for cultivar City of Portland (69.2 cm in 2011). Thiophanate methyl treatment produced the highest plant height and the values were significantly different at $P<0.05$ from the control for all years and for all cultivars. Plant heights in charcoal dust treatments were larger than the control treatments but it was not significantly different. 


\section{Conclusions}

According to above results, $C$. $x$ generalis is a big ornamental plant species but the size of the plants varies greatly. Among the three cultivars, the largest cultivar was Robert Kemp which produced the largest leaf number and plant height in all treatments and years. This cultivar, among the tested ones, seems to be the most suitable for city park decorations.

\section{Acknowledgements}

This research was partly supported by grants of the Hungarian Scientific Research Fund (K78399 and K108333) and the NKTH-OM-00227/2008 as well as by a by the European Union and the State of Hungary, co-financed by the European Social Fund in the framework of TÁMOP-4.2.4.A/ 211/1-2012-0001 'National Excellence Program' under project number A2-SZJ-TOK-13-0061. János Bolyai Research Fellowship awarded to Imre J. Holb.

\section{References}

Doi, M., Nakamura, N., Takizawa, Y., Wakita, M., Shimizu, F., Kitamura, Y., Hosokawa, M. (2013): Harvest characteristics of Canna $\times$ generalis L.H. Bailey leaves. Scientia Horticulturae 150: 441-447.

Maas-van de Kamer, H., Maas, P.J.M. (2008): The Cannaceae of the world. Blumea 53: 247-318.

Wróblewska, H., Schroeter-Zakrzewska, A., Głuchowska, K., Wolna-Maruwka, A., Kleiber, T. (2014): Application of post-consumer wood composts in canna lily (Canna $x$ generalis L.H. Bailey) cultivation. Drewno 57(191): 5-25.

Zhang, Z. H., Rengel, Z., Meney, K. (2004): Kinetics of ammonium, nitrate and phosphorus uptake by Canna indica and Schoenoplectus validus. Aquatic Botany 91(2): 71-74.

Yeh, D.M., Hsu, P.H., Atherton, J.G. (2004): Growth and flowering responses of Canna $\times$ generalis to nitrogen supplied to the growing medium via top- or sub-irrigation. Journal of Horticultural Science and Biotechnology A 79(4): 511-514.

Broschat, T. K.; Sandrock, D. R.; Elliott, M. L. et al. (2008): Effects of fertilizer type an quality and nutrient content of established landscape plants in Florida. HortTechnology 18(2): 278-285.

Cross, J.V., Dickler, E. (1994): Guidelines for integrated production of pome fruits in Europe. Technical guideline III. IOBC/WPRS Bulletin 17(9): 1-8. 